\title{
REVIEW
}

\section{The Met oncogene and basal-like breast cancer: another culprit to watch out for?}

\author{
Stefania Gastaldi, Paolo M Comoglio and Livio Trusolino*
}

\begin{abstract}
Recent findings suggest the involvement of the MET oncogene, encoding the tyrosine kinase receptor for hepatocyte growth factor, in the onset and progression of basal-like breast carcinoma. The expression profiles of basal-like tumors - but not those of other breast cancer subtypes - are enriched for gene sets that are coordinately over-represented in transcriptional signatures regulated by Met. Consistently, tissue microarray analyses have revealed that Met immunoreactivity is much higher in basal-like cases of human breast cancer than in other tumor types. Finally, mouse models expressing mutationally activated forms of Met develop a high incidence of mammary tumors, some of which exhibit basal characteristics. The present review summarizes current knowledge on the role and activity of Met in basal-like breast cancer, with a special emphasis on the correlation between this tumor subtype and the cellular hierarchy of the normal mammary gland.
\end{abstract}

The Met receptor in normal physiology and disease The Met tyrosine kinase receptor for hepatocyte growth factor (HGF) fosters invasive growth, a complex physiological program that implies the concerted activation of cell proliferation, survival, invasion and angiogenesis [1-4] (Figure 1). Met-regulated invasive growth plays important roles under physiological conditions - during development and tissue regeneration and controls cancer invasion and metastasis $[3,5]$.

In embryonic life, Met is expressed by epithelial and myoblast progenitors, whereas HGF is secreted by mesenchymal cells [6,7]. The paracrine stimulation of Met by HGF is essential for placenta and liver development and for migration of myoblast precursors [8-10]. In

*Correspondence: livio.trusolino@ircc.it

Institute for Cancer Research and Treatment (IRCC), University of Torino Medical School, 10060 Candiolo, Torino, Italy adulthood, the invasive growth program triggered by Met activation, when reversibly executed in space and time, is commonly associated with organ repair $[11,12]$. In contrast, derailment of Met-dependent signals promotes the progression and invasiveness of a large number of human cancers. In this context, Met hyperactivation is usually due to transcriptional upregulation, which is in turn induced by oncogenic alterations or microenvironmental stimuli. In a fraction of cases, constitutive firing of Met can be caused by genomic amplification, by point mutations, or by the presence of ligand autocrine loops [13-16]. High levels of HGF and/or Met overexpression correlate with the aggressive phenotype of different carcinomas, including those of the prostate, stomach, pancreas, thyroid and breast [17-20].

\section{The Met receptor in breast cancer}

In past years, a large number of clinical studies have described Met-receptor overexpression and pathway hyperactivation in tissues derived from breast cancer patients, and have found a strong relationship between high HGF/Met signaling and tumor progression (Table 1). Indeed, the HGF content in breast tumor tissue correlates with the aggressive phenotype, being higher in invasive ductal carcinomas than in ductal carcinomas in situ and benign hyperplasia $[21,22]$. In normal mammary tissue HGF is expressed by stromal cells surrounding the epithelial compartment, whereas in cancer the ligand can be produced de novo by carcinoma cells that also express the receptor, thus generating an autocrine loop that predicts poor prognosis [16]. Moreover, in many cases HGF and Met are co-expressed in correspondence of the advancing margins of mammary tumors, a finding that goes along with high histological grade and high proliferative index [23]. In axillary lymph node-negative patients, Met overexpression is significantly associated with reduced survival, with a 5-year survival rate of $62 \%$ compared with $97 \%$ of Met low-expressing patients. The follow-up of these patients revealed that in many cases Met expression was negligible at the time of diagnosis but increased in late recurrences, thus suggesting a possible selection of Met-overexpressing clones in relapse and metastasis [24]. 


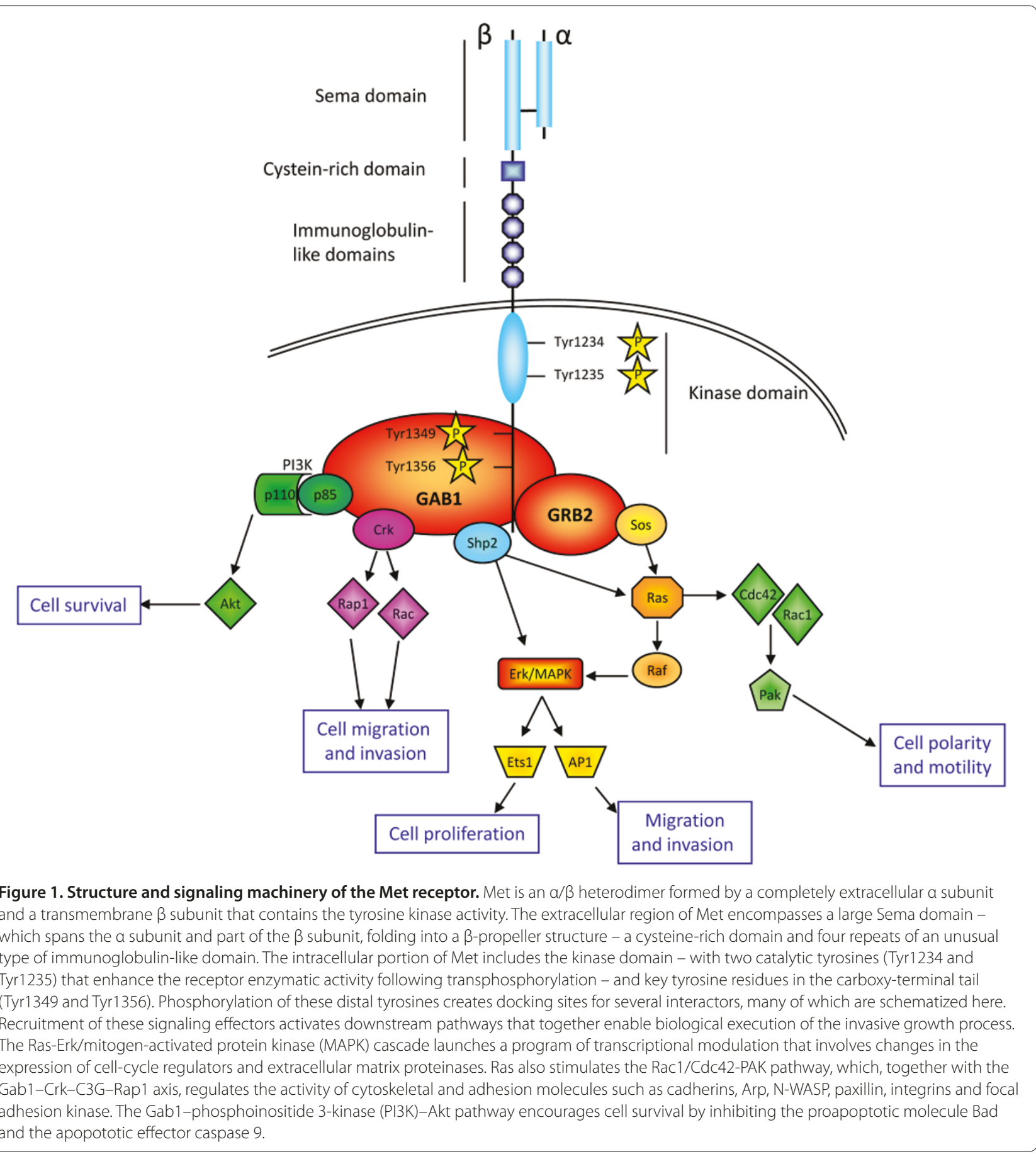

Clinical data are supported by animal models of Metdriven mammary tumorigenesis: transgenic mice in which HGF has been specifically targeted to the mammary epithelium using the Whey-acidic-protein promoter display a hyperplastic ductal tree with multifocal invasive tumors [25]. Similarly, primary cultures of mammary cells overexpressing Met develop nonprogressive neoplasms upon orthotopic implantation in recipient mice; such lesions are able to progress to adenocarcinomas when the proto-oncogene Myc is ectopically overexpressed together with Met [26].

\section{Molecular classification of human breast cancer recalls the cellular hierarchy of the normal mammary gland}

Human breast cancer is a heterogeneous disease that comprises a variety of pathologies with different histological features and clinical outcomes. On the basis of 
Table 1. Summary of HGF/Met alterations in breast cancer

\begin{tabular}{|c|c|c|}
\hline Reference & Observations/lesions & Clinical/biological aspects \\
\hline Yao and colleagues [21] & High levels of HGF in breast tumor tissue & Invasive ductal carcinomas \\
\hline Tuck and colleagues [16] & HGF/Met autocrine loop in tumor cells & Co-localization at the advancing margins of the tumors \\
\hline Jin and colleagues [22] & High levels of HGF and c-Met overexpression in breast tissue & Invasive ductal carcinomas \\
\hline Camp and colleagues [24] & Met overexpression & Reduced survival, relapse and metastatic dissemination \\
\hline Edakuni and colleagues [23] & Met overexpression & $\begin{array}{l}\text { High histological grade, proliferative index, advancing } \\
\text { margins }\end{array}$ \\
\hline Kang and colleagues [82] & High levels of Met and HGF in node-negative breast cancer & Tumor progression and poor patient outcome \\
\hline Lengyel and colleagues [83] & Met overexpression in node-positive breast cancer & $\begin{array}{l}\text { Disease progression and decrease in disease-free } \\
\text { survival }\end{array}$ \\
\hline Charafe-Jauffre and colleagues [43] & Met overexpression in breast cancer cell lines & Basal-like phenotype \\
\hline Lindemann and colleagues [84] & $\begin{array}{l}\text { Imbalance in Met expression between tumor and normal } \\
\text { tissue }\end{array}$ & Aggressive ductal carcinoma in situ \\
\hline Eichbaum and colleagues [85] & High HGF serum levels & Liver metastatic colonization from breast cancer \\
\hline Garcia and colleagues [45] & Met overexpression in tissue microarrays & Poor prognosis, basal-like phenotype \\
\hline Finkbeiner and colleagues [49] & Transcriptional upregulation of Met & $\begin{array}{l}\text { Anchorage-independent growth of basal-like breast } \\
\text { cancer cells }\end{array}$ \\
\hline Smolen and colleagues [65] & $\begin{array}{l}\text { Met amplification in a Brca1-p53 mouse model of breast } \\
\text { cancer }\end{array}$ & Mouse mammary tumor progression \\
\hline Ponzo and colleagues [53] & MMTV-Met mutant transgenic mice & $\begin{array}{l}\text { Heterogeneous mammary tumors, basal-like } \\
\text { phenotype }\end{array}$ \\
\hline Graveel and colleagues [52] & Met mutant knock-in mice & $\begin{array}{l}\text { Mammary tumors associated with basal-like } \\
\text { phenotype }\end{array}$ \\
\hline
\end{tabular}

HGF, hepatocyte growth factor; MMTV, mouse mammary tumor virus promoter.

gene expression profiles obtained from cDNA microarray analysis of a large set of tumor samples, Sorlie and colleagues defined a new molecular classification of human breast cancers [27]. According to this classification, breast tumors have been clustered into five different subtypes: luminal A, luminal B, Her2-overexpressing, normal-like and basal-like. This classification reflects the characteristics of the cell populations that are present in the normal epithelium of the mammary gland. In fact, besides highlighting the molecular heterogeneity of breast tumor subtypes, the transcriptional profiles revealed a molecular/phenotypic connection between the transformed cells and the normal epithelial counterpart. Based on this observation, it has been proposed that the different types of breast cancer have their cell of origin in the different subpopulations that constitute the normal mammary gland under physiological conditions.

\section{The cell hierarchy of the normal mammary gland}

The mature mammary epithelium is composed of three main epithelial cell types: the basal/myoepithelial cells, which line the outer side of the ducts; and the luminal cells, which are further distinguished into ductal and alveolar elements and form the inner side of the ducts and the alveoli, respectively. According to molecular profiling, it is assumed that the luminal subtype arises from cells belonging to the luminal lineage, whilst the basal subtype is supposed to derive from less differentiated cells of the gland - such as stem/progenitor cells that are normally located within the basal/myoepithelial compartment and exhibit basal phenotypic markers.

The epithelial cells of the mammary gland are organized in a hierarchical manner, with stem cells and progenitor cells giving rise to all the different lineages that are present in the mature gland. The stem cells, also called mammary repopulating units, are capable of selfrenewal and generate all of the cellular types that make up the mammary gland [28]. The existence of a stem cell population has been postulated for a long time because of the ability of the mammary gland to go through several cycles of proliferation and involution during pregnancies, and due to the fact that the transplantation of mammary fragments into the fat pad of receiving animals is sufficient to form a mature mammary tree $[29,30]$. The immediate progeny of stem cells identifies the compartment of progenitors, which is composed of actively proliferating cells endowed with a limited differentiation potential. Progenitor cells are also called mammary colony-forming units because of their ability to efficiently generate clonal aggregates when cultured in vitro [31].

The recent identification of surface markers characteristic of the distinct subpopulations, from undifferentiated cells to mature cells, allowed their prospective isolation and biological characterization. Two independent 
groups were able to isolate mouse mammary repopulating units and progenitor cells on the basis of the differential expression of the surface markers CD24, CD49f and CD29. Stingl and colleagues identified mammary repopulating units on the basis of a CD $24^{+} \mathrm{CD} 49 \mathrm{f}^{\text {high }}$ phenotype, while Shackleton and coworkers defined the stem cell subpopulation as $\mathrm{Lin}^{-} \mathrm{CD} 24^{+} \mathrm{CD} 29^{\text {high }}[31,32]$. Both groups demonstrated the ability of these cells to selfrenew and to generate a completely functional mammary gland even after transplantation of one single cell. A subset of progenitors committed to the luminal lineage was isolated based on the expression of CD61 and low levels of CD133 and Sca1. These cells can terminally differentiate into mature luminal cells, which lose CD61 expression and increase expression of CD133 and Sca1 [33,34].

\section{Mammary epithelial subpopulations and types of breast cancer}

As mentioned before, the different types of breast cancer probably reflect a distinct cell of origin present along the hierarchical organization of the normal mammary gland. Indeed, the luminal subtype is characterized by high expression of genes of the luminal compartment, including estrogen receptor alpha $(\mathrm{ER} \alpha)$, cytokeratin 18, the transcription factor GATA3 and estrogen-regulated genes; this group is further subdivided into type $\mathrm{A}$ and type $B$, which differ for the level of expression of $E R \alpha$, the proliferation index (assessed by Ki67 staining), and the clinical outcome [35]. The Her2 subtype is characterized by overexpression of the Her2 protein on the cell membrane, due to genomic amplification of the region $17 q 22.24$ that includes the genes coding for Her2 and growth factor receptor-bound protein 7 . The normal breast signature defines a group of tumors with high expression of genes of adipose cells and other nonepithelial cell types, as well as low levels of luminal markers. Finally, tumors belonging to the basal-like subgroup express high levels of basal markers, such as cytokeratins 5/14/17 and laminin, and do not express $\mathrm{ER} \alpha$, progesterone receptor and Her2. Notably, it was initially assumed that the cell of origin of this tumor subtype was to be found in the stem cells of the basal compartment. Recent gene expression profiling of the different subpopulations in the human normal mammary gland and analysis of tumors with basal-like features, however, showed that this tumor phenotype appears to be more similar to the gene signature derived from the luminal progenitor population [36].

The molecular classification of breast cancer has an important prognostic value: the single subtypes have different prognosis and show different responsiveness to specific therapies. The luminal tumors are those with a better outcome and a wider possibility of treatment: ER $\alpha$ is preferentially expressed in terminally differentiated luminal cells and, accordingly, luminal tumors exhibit a differentiated morphology with almost benign features. More importantly, the mitogenic activity of estrogen can be counteracted by endocrine agents such as tamoxifene and aromatase inhibitors [37,38]. In the case of the Her2 group, tumors are endowed with a more aggressive phenotype, but overexpression of Her2 makes the majority of such tumors highly responsive to Her2 inhibition obtained with the specific monoclonal antibody trastuzumab (Herceptin) [39].

Among the different subgroups, the basal-like breast cancers (BLBCs) are those that have the worst clinical outcome: they represent 15 to $20 \%$ of human breast cancer and are characterized by an aggressive phenotype with high histological grade, pushing borders, large areas of necrosis and high mitotic indexes. The majority of BLBCs does not express hormone receptors (ER $\alpha$ and progesterone receptor) and is negative for Her2; they are therefore called triple-negative tumors [40,41]. Their molecular features render these tumors especially difficult to treat with anti-hormonal approaches; moreover, the lack of understanding of the genes and processes involved in transformation and progression of this tumor subtype makes it difficult to target with last-generation tailored therapies. As for conventional chemotherapeutics, BLBCs appear to be more sensitive than luminal subtypes to neoadjuvant anthracycline-based regimens, which could be explained by the fact that anthracyclines work efficiently on hyperproliferating cells and that the proliferation-related gene set is highly represented in this subtype; yet BLBCs have poor survival due to higher relapse rate following incomplete pathologic response [42]. In this scenario, the identification of causative, targetable biomarkers for the basal subtype, which could be challenged for prospective therapies, remains an unmet clinical need.

\section{Met and basal-like breast cancer}

Together with patient-derived material, breast cancer cell lines have been utilized as tools to identify new markers for the study of breast tumor subtypes. Both genomewide expression profiling and proteomic approaches led to the classification of cell lines in two major clusters: the luminal group and the basal group. Similar to data obtained from surgical specimens, genes overexpressed in the luminal cluster include ER $\alpha$, GATA3, cytokeratin 19 and genes associated with ER-positive status, such as cytokeratin 8 , cytokeratin 18 and mucin 1 . The basal cluster is typified by high expression of cytokeratins 5/14/17, integrin $\alpha_{6}$, integrin $\beta_{4}$, CD44, CD10 and caveolin 1 . Interestingly, these large-scale analyses allowed the identification of new basal markers: together with other tyrosine kinases, including the epidermal growth factor receptor (EGFR) and c-Kit, Met emerged as one of 
the most differentially regulated genes in the basal cluster versus the luminal cluster $[43,44]$.

These results have been confirmed in tissue microarraybased clinical studies on a large number of breast carcinomas [44-47]. A cohort of 930 tumor samples, subdivided according to patient survival and lymph node status, was screened for expression of Met together with proteins known to be representative of the basal phenotype (cytokeratin 5, cytokeratin 6, caveolin 1, c-Kit, p63). High Met staining was found in tumors from deceased patients with highly invasive malignancies. Importantly, Met overexpression was consistently associated with co-expression of basal markers, thus pinpointing Met as an additional constituent of the basal phenotype [45]. Similar findings were obtained in an independent tissue microarray containing 1,600 specimens from 547 patients with early breast cancer [44] and in a more limited subset of metastatic tumors [46].

\section{Mechanistic insights}

A mechanistic link between Met and BLBCs is highlighted by the observation that receptor overexpression correlates with high expression levels of the transcription factor Y-box binding protein-1 (YB-1). An oncogenic transcriptional/translational factor, $\mathrm{YB}-1$ was originally identified by screening an expression library for DNAbinding proteins able to interact with the EGFR enhancer and with the Her2 promoter region [48]. A recent survey of candidate DNA-binding regions showed that $\mathrm{YB}-1$ can bind to more than 6,000 promoters, among which promoters of kinases and growth factor receptors are highly represented [49]. YB-1 is highly expressed in more than $70 \%$ of basal-like cancers, and its expression correlates with poor survival and high risk of relapse [50]. YB-1 is also expressed in normal mammary bipotent progenitor cells, but the level of the protein is much lower than that observed in tumors. This differential expression is in line with a functional role for this transcription factor in tumor onset and progression.

Among the transcriptional targets of $\mathrm{YB}-1$ there are several genes representative of the basal-like signature, including Met [49,51]. Chromatine immunoprecipitation analysis indicated that YB-1 binds directly to the Met promoter in a region that resides $-1,080 \mathrm{bp}$ from the translational starting site, thus driving Met expression. YB-1 and Met are both highly expressed in cell lines belonging to the basal cluster, and the downmodulation of YB-1 produces a reduction in the levels of Met, together with an impairment of cell proliferation and anchorage-independent growth. Neither YB-1 nor the Met gene appeared to be amplified in basal cell lines, indicating that the main mechanism leading to overexpression of both molecules is probably based on transcriptional/translational regulation [49].

\section{Met and mouse models of basal-like breast cancer}

Recently, two different mouse models of conditional expression of oncogenic Met variants in the mammary gland demonstrated a causal role for Met in the onset of diverse types of mammary tumors, including BLBCs. In the first model, the oncogenic mutant of Met, containing activating missense mutations within the tyrosine kinase domain, was knocked-in downstream from the Met endogenous promoter [52]; in the second model, transforming isoforms of Met were transgenically expressed in the mammary epithelium under the control of the mouse mammary tumor virus promoter [53]. Oncogenic Met knock-in mice developed a spectrum of mammary cancers (solid adenocarcinomas, adenosquamous carcinomas, and myoepitheliomas), with some of them displaying histological, cytogenetic, and phenotypic characteristics typical of basal-like cancers, such as cytokeratin 5 expression and absence of progesterone receptor and Her2 expression. Similarly, transgenic mice with mouse mammary tumor virus promoter-driven expression of mutant Met developed tumors with a high degree of morphological heterogeneity, including solid/ luminal features and lesions with papillary, scirrhous, adenosquamous, or spindle-cell phenotypes. Gene expression profiling for this latter mixed-pathology group revealed that such tumors have an enrichment of basal markers as well as genes associated with epithelialmesenchymal transition; for instance, Snail [53].

Analysis of Met expression in a cohort of human breast cancer samples showed that tumors with the highest levels of Met correlate with the basal subtypes, and breast cancers with a transcriptional signature indicative of Met activation mainly fall within the basal cluster. Among these tumors, those with active Met expression profiling had a worse prognosis and a shorter disease-free survival [52]. These transcriptional data have been recently corroborated by genome-wide copy number analysis in BLBC cell lines: although focal amplification of MET was not detected, specific enrichment of the HGF/Met pathway was reflected in frequent copy number gains and overexpression of key adapter molecules and downstream signal transducers [54].

In sum, studies performed in cell lines, in patientderived material, and in animal models provide a clear indication that Met is preferentially expressed (or is mainly active) in BLBCs with respect to other subtypes of breast cancer. While this is certainly true, it should be noted that Met overexpression can be observed sporadically also in nonbasal-like tumors: for example, increased levels of Met are detectable in some cases of Her2-positive and ER-positive mammary carcinomas $[52,53]$. Something similar also applies to other tyrosine kinase receptors, including EGFR and c-Kit: their expression strongly correlates with BLBCs, but these 
oncogenes are not uniquely expressed in this tumor subtype [40]. Indeed, when taken individually, none of the markers of the basal cluster can function as independent predictors. These markers do, however, comprehensively define an algorithm that significantly segregates BLBCs versus other breast cancer entities.

\section{Met, BRCA1 mutated cancer and the basal phenotype}

The basal-like group also includes a type of familial breast cancer that arises in BRCA1 mutation carriers. The presence of germline BRCA1 mutations increases the risk of developing breast cancer and ovarian cancer in young women [55]. The pathologic and molecular features of breast cancers arising in BRCA1 mutation carriers resemble those observed in the basal-like subtype: such tumors have a high histological grade, high proliferation indexes and pushing borders, and lack ER $\alpha$, progesterone receptor and Her2 expression [56,57].

\section{The molecular function of BRCA1}

One of the main activities of BRCA1 involves the regulation of DNA double-strand break repair through the process of homologous recombination. Tumor cells that lack BRCA1 expression are hence relatively sensitive to DNA-damaging agents [58]. These cells are particularly responsive to chemical inhibition of poly(ADP-ribose) polymerase, which leads to the accumulation of DNA single-strand breaks that are then converted into DNA double-strand breaks during replication [59-61]. In normal cells, the DNA double-strand breaks are fixed by repair mechanisms involving BRCA1; in cells lacking BRCA1, these lesions are repaired by error-prone systems, such as nonhomologous end joining, with the consequent accumulation of mutations and complex chromosomal rearrangements that ultimately lead to cell death [62].

Tumors arising in BRCA1-mutated patients are characterized by the presence of somatic inactivating mutations of p53 [63,64]. Genomic instability caused by BRCA1 loss would normally lead to cell-cycle arrest through the p53mediated DNA damage checkpoint, and eventually to apoptosis. The concomitant loss of function of p53 affords cells the ability to bypass this checkpoint block and to continue unscheduled proliferation in the face of severe chromosomal instability. In this condition, the ensuing occurrence of secondary lesions is likely to contribute to full-blown neoplastic transformation [65].

\section{Met, BRCA1 and mouse models of basal-like breast cancer}

Met overexpression has been associated with experimental tumors arising in a BRCA1 mutated context, specifically in a mouse model in which BRCA1 and p53 were conditionally deleted in the mammary epithelium
[65]. A genome-wide screening of tumors developed in these mice revealed that the most common genetic alteration was amplification of the Met locus $(73 \%$ of cases). As a consequence, these tumors expressed high levels of Met mRNA and protein. The amplification was associated with extra-chromosomal double minutes; these are unstable genomic elements that were detected in vivo by fluorescence in situ hybridization analysis of mouse-derived tumors but were rapidly lost in primary cultures, probably because double minutes are maintained only in the presence of in vivo selection pressures within the breast microenvironment.

It is noteworthy that Met amplification in the form of extrachromosomal double minutes is also a primary alteration in the mutant Met knock-in mice that develop basal-like breast tumors [52]. Together, these findings suggest that Met amplification may be a common event in murine mammary tumorigenesis. Focal amplification of the MET gene, however, is not a common finding in human breast cancer: interphase fluorescence in situ hybridization performed on a human breast cancer tissue microarray did not reveal any amplification of the Met genomic locus [65], and this genetic alteration has not so far been reported for BRCA1 mutation carriers. A more frequent occurrence is low-grade polysomy (three to five copies) of chromosome 7 - where the MET locus resides which is detected in approximately $25 \%$ of human ductal infiltrating carcinomas [66].

\section{Met and epidermal growth factor receptor in basal-like breast cancer}

Another tyrosine kinase that phenotypically marks basallike breast tumors is EGFR. Similar to Met, EGFR is highly expressed in the majority of BLBCs in vivo and exerts proliferative and anti-apoptotic functions in cultured basal-like breast cancer cells [43]. In preclinical studies, EGFR inhibition can potentiate cisplatin-induced apoptosis in cultured basal-like breast cells [67].

\section{Clinical trials with epidermal growth factor receptor inhibitors} Based on these observations, clinical trials have been designed to study the effect of EGFR inhibition in patients with BLBC. Two studies completed to date have provided interlocutory results. TBCRC 001 was a randomized phase II trial evaluating the role of EGFR inhibition for triple-negative metastatic breast cancer. In this study, eligible women received the anti-EGFR monoclonal antibody cetuximab combined with carboplatin, or received cetuximab alone with a planned crossover to carboplatin at progression. Cetuximab alone showed a low response rate and this trial arm was closed before time; response to the combination of cetuximab plus carboplatin was $17 \%$, with clinical benefit seen in $29 \%$ of a pretreated population [68]. A similar study examining 
Table 2. Summary of HGF/Met inhibitors currently in clinical trials

\begin{tabular}{|c|c|c|c|c|}
\hline Agent & Type & Targets & $\begin{array}{l}\text { Phase of } \\
\text { development }\end{array}$ & Comments \\
\hline AMG102 (Amgen) & Antibody & Human HGF & Phase $1 / 2$ & $\begin{array}{l}\text { Tested in small-cell lung cancer, metastatic colorectal } \\
\text { carcinoma, malignant glioma, prostate cancer, renal cell } \\
\text { carcinoma, gastric or esophagogastric junction cancer, } \\
\text { mesothelioma, ovarian cancer or peritoneal cancer }\end{array}$ \\
\hline $\begin{array}{l}\text { SCH900105 } \\
\text { (Aveo Pharmaceuticals) }\end{array}$ & Antibody & Human HGF & Phase $1 / 2$ & Tested in nonsmall-cell lung cancer \\
\hline MetMab (Genentech) & Monovalent antibody & Human Met & Phase $1 / 2$ & Tested in nonsmall-cell lung cancer \\
\hline ARQ197 (ArQule) & $\begin{array}{l}\text { Selective small-molecule } \\
\text { inhibitor, non-ATP } \\
\text { competitive }\end{array}$ & Met & Phase 1/2 & $\begin{array}{l}\text { Tested in nonsmall-cell lung cancer, metastatic } \\
\text { colorectal carcinoma, pancreatic adenocarcinoma, } \\
\text { hepatocellular carcinoma, gastric carcinoma, germ cell } \\
\text { tumors, renal cell carcinoma, alveolar soft part sarcoma, } \\
\text { clear cell sarcoma }\end{array}$ \\
\hline $\begin{array}{l}\text { JNJ-38877605 } \\
\text { (Johnson and Johnson) }\end{array}$ & $\begin{array}{l}\text { Selective small-molecule } \\
\text { inhibitor, ATP competitive }\end{array}$ & Met & Phase 1 & \\
\hline $\begin{array}{l}\text { EMD-1214063 } \\
\text { (EMD Serono) }\end{array}$ & $\begin{array}{l}\text { Selective small-molecule } \\
\text { inhibitor, ATP competitive }\end{array}$ & Met & Phase 1 & \\
\hline INCB-028060 (Incyte) & $\begin{array}{l}\text { Selective small-molecule } \\
\text { inhibitor, ATP competitive }\end{array}$ & Met & Phase 1 & \\
\hline MK-8033 (Merck) & $\begin{array}{l}\text { Selective small-molecule } \\
\text { inhibitor, ATP competitive }\end{array}$ & $\begin{array}{l}\text { Met, Ron } \\
\text { (10-fold less active) }\end{array}$ & Phase 1 & \\
\hline PF-02341066 (Pfizer) & $\begin{array}{l}\text { Multikinase inhibitor, } \\
\text { ATP competitive }\end{array}$ & Met, ALK & Phase $1 / 2$ & Tested in nonsmall-cell lung cancer \\
\hline $\begin{array}{l}\text { GSK-1363089/XL880 } \\
\text { (Exelixis) }\end{array}$ & $\begin{array}{l}\text { Broad-spectrum kinase } \\
\text { inhibitor, ATP competitive }\end{array}$ & $\begin{array}{l}\text { Met, Ron, VEGFR1 } \\
\text { to VEGFR3, PDGFR, } \\
\text { Kit, Flt-3, Tie-2 }\end{array}$ & Phase $1 / 2$ & $\begin{array}{l}\text { Tested in gastric cancer, nonsmall-cell lung cancer, } \\
\text { papillary renal-cell carcinoma }\end{array}$ \\
\hline $\begin{array}{l}\text { BMS-907351/XL184 } \\
\text { (Exelixis) }\end{array}$ & $\begin{array}{l}\text { Broad-spectrum kinase } \\
\text { inhibitor, ATP competitive }\end{array}$ & $\begin{array}{l}\text { Met, VEGFR2, Ret, } \\
\text { Kit, Flt-3, Tie-2 }\end{array}$ & Phase 1/2/3 & $\begin{array}{l}\text { Tested in medullary thyroid cancer, nonsmall-cell lung } \\
\text { carcinoma, glioblastoma, astrocytic tumors }\end{array}$ \\
\hline MP470 (SuperGen) & $\begin{array}{l}\text { Broad-spectrum kinase } \\
\text { inhibitor, ATP competitive }\end{array}$ & $\begin{array}{l}\text { Met, Ret, Rad51, } \\
\text { mutant forms of Kit, } \\
\text { PDGFR, Flt-3 }\end{array}$ & Phase 1b & $\begin{array}{l}\text { Tested in neuroendocrine tumors, lung cancer, } \\
\text { triple-negative breast cancer }\end{array}$ \\
\hline MGCD265 (Methylgene) & $\begin{array}{l}\text { Broad-spectrum kinase } \\
\text { inhibitor, ATP competitive }\end{array}$ & $\begin{array}{l}\text { Met, Ron, VEGFR1 } \\
\text { to VEGFR3, Kit, } \\
\text { Flt-3, Tie-2 }\end{array}$ & Phase 1 & \\
\hline MK-2461 & $\begin{array}{l}\text { Broad-spectrum kinase } \\
\text { inhibitor, ATP competitive }\end{array}$ & $\begin{array}{l}\text { Met, KDR, FGFR1 } \\
\text { to FGFR3, Flt-1, } \\
\text { Flt-3, Flt-4 }\end{array}$ & $\begin{array}{l}\text { Phase } 1 \\
\text { completed }\end{array}$ & \\
\hline
\end{tabular}

FGFR, fibroblast growth factor receptor; HGF, hepatocyte growth factor; PDGFR, platelet-derived growth factor receptor; VEGFR, vascular endothelial growth factor receptor.

irinotecan plus carboplatin with or without cetuximab showed a modestly higher response rate (from 30 to $49 \%$ ) with the cetuximab combination [68].

These interim data together indicate that targeted therapies against EGFR in breast tumors appear to be poorly effective with respect to other types of cancer in which EGFR deregulation has been documented, such as lung cancer and colon cancer [69-71]. This lack of effect could be due, at least in principle, to the presence of concomitantly active signal transduction pathways emanating from other tyrosine kinase receptors, including Met.

\section{The Met-epidermal growth factor receptor connection}

Several pieces of evidence point to an intimate relationship between EGFR and Met signaling, both in physiological settings, such as mammary gland morphogenesis [72], and in pathologic conditions, including cancer progression and resistance to targeted therapies. In nonsmall-cell lung carcinomas, for example, the onset of secondary resistance to EGFR inhibition relies, among other things, on the acquisition of MET gene amplification and consequent protein overexpression, which leads to activation of signal transduction cascades that compensate for EGFR blockade and sustain tumor maintenance [73-75]. Something similar might also occur in mammary tumors. Met and EGFR are both overexpressed in breast cancer cell lines endowed with a basal-like subtype molecular profile [42]. In this context, resistance to the EGFR inhibitor gefitinib occurs because EGFR is trans-phosphorylated via a Met/Src-mediated 
signaling pathway. Accordingly, cancer cell proliferation can be impaired by combined neutralization of EGFR and Met signals [76].

Together with Met and EGFR, other tyrosine kinase receptors have been reported to be overexpressed in basal-like breast carcinoma: among these prominent druggable targets are c-Kit and the fibroblast growth factor receptor. High levels of c-Kit are preferentially found in BRCA1-associated basal-like tumors; of note, cKit mRNA expression appears to be already twofold higher in preneoplastic BRCA1 mutation-associated breast tissue versus non-BRCA1/2 breast tissue, suggesting that $\mathrm{c}$-Kit upregulation may be an early event in BRCA1-driven tumorigenesis [36]. Fibroblast growth factor receptor has been shown to be amplified at the genomic level in two BLBC cell lines; both lines undergo apoptosis following pharmacologic or RNA interferencemediated inactivation of the kinase [54].

\section{Conclusions}

Some of the genes described as belonging to the different subtypes of breast cancer have been reported to play important roles in the definition of a specific cell lineage in normal mammary development and to be deregulated in the tumors that recapitulate the characteristics of that specific lineage. For example, the transcription factor GATA3 mediates luminal differentiation in gland development and GATA3 deficiency leads to a block in luminal terminal differentiation, with an expansion of the progenitor compartment [34,77]. Consistently, in the tumor counterpart, GATA3 is highly expressed in the luminal subtypes $[27,78]$.

When applying this line of thinking to the HGF/Met system, one could speculate that the correlation between Met expression and basal markers reflects a precise Met function in physiological gland development; namely, in the definition of a poorly differentiated basal compartment and/or in the negative regulation of luminal terminal differentiation. Future work is needed to address the role of Met in mammary lineage determination and to analyze whether Met activation can trigger a genetic/molecular program that dictates commitment to one specific mammary subpopulation with respect to the others.

While the association between high Met expression and human basal cancers is now well defined, the causative role for Met in the onset and/or maintenance of BLBCs is less clear: mice in which active forms of Met are specifically expressed in the mammary epithelium develop breast carcinomas with basal-like features, but they are also prone to tumors with phenotypic and molecular characteristics other than those of BLBCs $[52,53]$. To tackle this issue at the clinical level, it will be interesting to explore whether targeting of Met in basallike cancer will have therapeutic value. Several anti-Met antibodies and small-molecule Met inhibitors have been recently developed, and many of them are now being tested in phase 1 and phase 2 clinical trials [79-81] (Table 2). These agents will probably prove useful in combination with other therapies, including EGFR, c-Kit, and fibroblast growth factor receptor inhibitors. At present, the availability of mouse models that develop Met-driven basal-like breast tumors provides a useful experimental platform to assay the efficacy of Met inhibition in the preclinical setting and to guide future intervention in human patients.

\section{Abbreviations}

$B L B C$, basal-like breast cancer; EGFR, epidermal growth factor receptor; ERa, estrogen receptor alpha; HGF, hepatocyte growth factor; YB-1, Y-box binding protein-1.

\section{Competing interests}

The authors declare that they have no competing interests.

\section{Acknowledgements}

The authors thank Carla Boccaccio and the authors' colleagues from the Laboratory of Molecular Pharmacology at the Institute for Cancer Research and Treatment (IRCC) for comments and suggestions. Work in the authors laboratory is funded by grants from Associazione Italiana per la Ricerca sul Cancro, Regione Piemonte, and Ministero dell'Università e della Ricerca.

\section{Published: 23 August 2010}

\section{References}

1. Naldini L, Weidner KM, Vigna E, Gaudino G, Bardelli A, Ponzetto C, Narsimhan RP, Hartmann G, Zarnegar R, Michalopoulos GK, Birchmeier W, Comoglio PM: Scatter factor and hepatocyte growth factor are indistinguishable ligands for the MET receptor. EMBO J 1991, 10:2867-2878.

2. Bottaro DP, Rubin JS, Faletto DL, Chan AM, Kmiecik TE, Vande Woude GF, Aaronson SA: Identification of the hepatocyte growth factor receptor as the c-met proto-oncogene product. Science 1991, 251:802-804.

3. Boccaccio C, Comoglio PM: Invasive growth: a MET-driven genetic programme for cancer and stem cells. Nat Rev Cancer 2006, 6:637-645.

4. Giordano S, Ponzetto C, Di Renzo MF, Cooper CS, Comoglio PM: Tyrosine kinase receptor indistinguishable from the c-met protein. Nature 1989, 339:155-156

5. Birchmeier C, Gherardi E: Developmental roles of HGF/SF and its receptor, the c-Met tyrosine kinase. Trends Cell Biol 1998, 8:404-410.

6. Sonnenberg E, Meyer D, Weidner KM, Birchmeier C: Scatter factor/ hepatocyte growth factor and its receptor, the c-met tyrosine kinase, can mediate a signal exchange between mesenchyme and epithelia during mouse development. J Cell Biol 1993, 123:223-235.

7. Andermarcher E, Surani MA, Gherardi E: Co-expression of the HGF/SF and c-met genes during early mouse embryogenesis precedes reciprocal expression in adjacent tissues during organogenesis. Dev Genet 1996, 18:254-266.

8. Bladt F, Riethmacher D, Isenmann S, Aguzzi A, Birchmeier C: Essential role for the c-met receptor in the migration of myogenic precursor cells into the limb bud. Nature 1995, 376:768-771.

9. Schmidt C, Bladt F, Goedecke S, Brinkmann V, Zschiesche W, Sharpe M, Gherardi E, Birchmeier C: Scatter factor/hepatocyte growth factor is essential for liver development. Nature 1995, 373:699-702.

10. Uehara Y, Minowa O, Mori C, Shiota K, Kuno J, Noda T, Kitamura N: Placental defect and embryonic lethality in mice lacking hepatocyte growth factor/ scatter factor. Nature 1995, 373:702-705.

11. Huh CG, Factor VM, Sanchez A, Uchida K, Conner EA, Thorgeirsson SS: Hepatocyte growth factor/c-met signaling pathway is required for efficient liver regeneration and repair. Proc Natl Acad Sci U S A 2004, 101:4477-4482.

12. Chmielowiec J, Borowiak M, Morkel M, Stradal T, Munz B, Werner S, Wehland J, Birchmeier C, Birchmeier W: c-Met is essential for wound healing in the skin. J Cell Biol 2007, 177:151-162. 
13. Schmidt L, Duh FM, Chen F, Kishida T, Glenn G, Choyke P, Scherer SW, Zhuang Z, Lubensky I, Dean M, Allikmets R, Chidambaram A, Bergerheim UR, Feltis JT, Casadevall C, Zamarron A, Bernues M, Richard S, Lips CJ, Walther MM, Tsui LC, Geil L, Orcutt ML, Stackhouse T, Lipan J, Slife L, Brauch H, Decker J, Niehans G, Hughson MD, et al:: Germline and somatic mutations in the tyrosine kinase domain of the MET proto-oncogene in papillary renal carcinomas. Nat Genet 1997, 16:68-73.

14. Park WS, Dong SM, Kim SY, Na EY, Shin MS, Pi JH, Kim BJ, Bae JH, Hong YK, Lee KS, Lee SH, Yoo NJ, Jang JJ, Pack S, Zhuang Z, Schmidt L, Zbar B, Lee JY: Somatic mutations in the kinase domain of the Met/hepatocyte growth factor receptor gene in childhood hepatocellular carcinomas. Cancer Res 1999, 59:307-310.

15. Ferracini R, Di Renzo MF, Scotlandi K, Baldini N, Olivero M, Lollini P, Cremona O, Campanacci M, Comoglio PM: The Met/HGF receptor is over-expressed in human osteosarcomas and is activated by either a paracrine or an autocrine circuit. Oncogene 1995, 10:739-749.

16. Tuck AB, Park M, Sterns EE, Boag A, Elliott BE: Coexpression of hepatocyte growth factor and receptor (Met) in human breast carcinoma. Am J Pathol 1996, 148:225-232.

17. Di Renzo MF, Olivero M, Giacomini A, Porte H, Chastre E, Mirossay L, Nordlinger B, Bretti S, Bottardi S, Giordano S, Plebani M, Gespach C, Comoglio PM: Overexpression and amplification of the met/HGF receptor gene during the progression of colorectal cancer. Clin Cancer Res 1995, 1:147-154.

18. Di Renzo MF, Olivero M, Serini G, Orlandi F, Pilotti S, Belfiore A, Costantino A, Vigneri R, Angeli A, Pierotti MA: Overexpression of the c-MET/HGF receptor in human thyroid carcinomas derived from the follicular epithelium. J Endocrinol Invest 1995, 18:134-139.

19. Humphrey PA, Zhu X, Zarnegar R, Swanson PE, RatliffTL, Vollmer RT, Day ML: Hepatocyte growth factor and its receptor (c-MET) in prostatic carcinoma. Am J Pathol 1995, 147:386-396.

20. Amemiya H, Kono K, Itakura J, Tang RF, Takahashi A, An FQ, Kamei S, lizuka H, Fujii H, Matsumoto Y: c-Met expression in gastric cancer with liver metastasis. Oncology 2002, 63:286-296.

21. Yao Y, Jin L, Fuchs A, Joseph A, Hastings HM, Goldberg ID, Rosen EM: Scatter factor protein levels in human breast cancers: clinicopathological and biological correlations. Am J Pathol 1996, 149:1707-1717.

22. Jin L, Fuchs A, Schnitt SJ, Yao Y, Joseph A, Lamszus K, Park M, Goldberg ID, Rosen EM: Expression of scatter factor and c-met receptor in benign and malignant breast tissue. Cancer 1997, 79:749-760.

23. Edakuni G, Sasatomi E, Satoh T, Tokunaga O, Miyazaki K: Expression of the hepatocyte growth factor/c-Met pathway is increased at the cancer front in breast carcinoma. Pathol Int 2001, 51:172-178.

24. Camp RL, Rimm EB, Rimm DL: Met expression is associated with poor outcome in patients with axillary lymph node negative breast carcinoma. Cancer 1999, 86:2259-2265.

25. Gallego MI, Bierie B, Hennighausen L: Targeted expression of HGF/SF in mouse mammary epithelium leads to metastatic adenosquamous carcinomas through the activation of multiple signal transduction pathways. Oncogene 2003, 22:8498-8508.

26. Welm AL, Kim S, Welm BE, Bishop JM: MET and MYC cooperate in mammary tumorigenesis. Proc Natl Acad Sci U S A 2005, 102:4324-4329.

27. Sorlie T, Perou CM, Tibshirani R, Aas T, Geisler S, Johnsen H, Hastie T, Eisen MB, van de Rijn M, Jeffrey SS, Thorsen T, Quist H, Matese JC, Brown PO, Botstein D, Eystein Lonning P, Borresen-Dale AL: Gene expression patterns of breast carcinomas distinguish tumor subclasses with clinical implications. Proc Natl Acad Sci U S A 2001, 98:10869-10874.

28. Stingl J: Detection and analysis of mammary gland stem cells. J Pathol 2009, 217:229-241.

29. Smith GH: Experimental mammary epithelial morphogenesis in an in vivo model: evidence for distinct cellular progenitors of the ductal and lobular phenotype. Breast Cancer Res Treat 1996, 39:21-31.

30. Kordon EC, Smith GH: An entire functional mammary gland may comprise the progeny from a single cell. Development 1998, 125:1921-1930

31. Stingl J, Eirew P, Ricketson I, Shackleton M, Vaillant F, Choi D, Li HI, Eaves CJ: Purification and unique properties of mammary epithelial stem cells. Nature 2006, 439:993-997.

32. Shackleton M, Vaillant F, Simpson KJ, Stingl J, Smyth GK, Asselin-Labat ML, Wu L, Lindeman GJ, Visvader JE: Generation of a functional mammary gland from a single stem cell. Nature 2006, 439:84-88.

33. Sleeman KE, Kendrick H, Robertson D, Isacke CM, Ashworth A, Smalley MJ: Dissociation of estrogen receptor expression and in vivo stem cell activity in the mammary gland. J Cell Biol 2007, 176:19-26

34. Asselin-Labat ML, Sutherland KD, Barker H, Thomas R, Shackleton M, Forrest NC, Hartley L, Robb L, Grosveld FG, van der Wees J, Lindeman GJ, Visvader JE: Gata-3 is an essential regulator of mammary-gland morphogenesis and luminal-cell differentiation. Nat Cell Biol 2007, 9:201-209.

35. Cheang MC, Chia SK, Voduc D, Gao D, Leung S, Snider J, Watson M, Davies S, Bernard PS, Parker JS, Perou CM, Ellis MJ, Nielsen TO: Ki67 index, HER2 status, and prognosis of patients with luminal B breast cancer. J Natl Cancer Inst 2009, 101:736-750

36. Lim E, Vaillant F, Wu D, Forrest NC, Pal B, Hart AH, Asselin-Labat ML, Gyorki DE, Ward T, Partanen A, Feleppa F, Huschtscha LI, Thorne HJ, Fox SB, Yan M, French JD, Brown MA, Smyth GK, Visvader JE, Lindeman GJ: Aberrant luminal progenitors as the candidate target population for basal tumor development in BRCA1 mutation carriers. Nat Med 2009, 15:907-913.

37. Cheung KL: Endocrine therapy for breast cancer: an overview. Breast 2007, 16:327-343.

38. Buzdar AU: Advances in endocrine treatments for postmenopausal women with metastatic and early breast cancer. Oncologist 2003, 8:335-341.

39. Nahta R, Esteva FJ: Trastuzumab: triumphs and tribulations. Oncogene 2007. 26:3637-3643.

40. Rakha EA, Reis-Filho JS, Ellis IO: Basal-like breast cancer: a critical review. $J$ Clin Oncol 2008, 26:2568-2581.

41. Yehiely F, Moyano JV, Evans JR, Nielsen TO, Cryns VL: Deconstructing the molecular portrait of basal-like breast cancer. Trends Mol Med 2006, 12:537-544.

42. Carey LA, Dees EC, Sawyer L, Gatti L, Moore DT, Collichio F, Ollila DW, Sartor Cl, Graham ML, Perou CM: The triple negative paradox: primary tumor chemosensitivity of breast cancer subtypes. Clin Cancer Res 2007, 13:2329-2334.

43. Charafe-Jauffret E, Ginestier C, Monville F, Finetti P, Adelaide J, Cervera N, Fekairi S, Xerri L, Jacquemier J, Birnbaum D, Bertucci F: Gene expression profiling of breast cell lines identifies potential new basal markers. Oncogene 2006, 25:2273-2284

44. Goncalves A, Charafe-Jauffret E, Bertucci F, Audebert S, Toiron Y, Esterni B, Monville F, Tarpin C, Jacquemier J, Houvenaeghel G, Chabannon C, Extra JM, Viens P, Borg JP, Birnbaum D: Protein profiling of human breast tumor cells identifies novel biomarkers associated with molecular subtypes. Mol Cell Proteomics 2008, 7:1420-1433.

45. Garcia S, Dales JP, Charafe-Jauffret E, Carpentier-Meunier S, Andrac-Meyer L, Jacquemier J, Andonian C, Lavaut MN, Allasia C, Bonnier P, Charpin C: Poor prognosis in breast carcinomas correlates with increased expression of targetable CD146 and c-Met and with proteomic basal-like phenotype. Hum Pathol 2007, 38:830-841.

46. Wu JM, Fackler MJ, Halushka MK, Molavi DW, Taylor ME, Teo WW, Griffin C, Fetting J, Davidson NE, De Marzo AM, Hicks JL, Chitale D, Ladanyi M, Sukumar S, Argani P: Heterogeneity of breast cancer metastases: comparison of therapeutic target expression and promoter methylation between primary tumors and their multifocal metastases. Clin Cancer Res 2008, 14:1938-1946.

47. Ponzo MG, Park M: The Met receptor tyrosine kinase and basal breast cancer. Cell Cycle 2010, 9:1043-1050.

48. Sakura H, Maekawa T, Imamoto F, Yasuda K, Ishii S: Two human genes isolated by a novel method encode DNA-binding proteins containing a common region of homology. Gene 1988, 73:499-507.

49. Finkbeiner MR, Astanehe A, To K, Fotovati A, Davies AH, Zhao Y, Jiang H, Stratford AL, Shadeo A, Boccaccio C, Comoglio P, Mertens PR, Eirew P, Raouf A, Eaves CJ, Dunn SE: Profiling YB-1 target genes uncovers a new mechanism for MET receptor regulation in normal and malignant human mammary cells. Oncogene 2009, 28:1421-1431.

50. Habibi G, Leung S, Law JH, Gelmon K, Masoudi H, Turbin D, Pollak M, Nielsen TO, Huntsman D, Dunn SE: Redefining prognostic factors for breast cancer: YB-1 is a stronger predictor of relapse and disease-specific survival than estrogen receptor or HER-2 across all tumor subtypes. Breast Cancer Res 2008, 10:R86.

51. To K, Fotovati A, Reipas KM, Law JH, Hu K, Wang J, Astanehe A, Davies AH, Lee L, Stratford AL, Raouf A, Johnson P, Berquin IM, Royer HD, Eaves CI, Dunn SE: Y-box binding protein-1 induces the expression of CD44 and CD49f leading to enhanced self-renewal, mammosphere growth, and drug resistance. Cancer Res, 70:2840-2851.

52. Graveel CR, DeGroot JD, Su Y, Koeman J, Dykema K, Leung S, Snider J, Davies SR, Swiatek PJ, Cottingham S, Watson MA, Ellis MJ, Sigler RE, Furge KA, Vande 
Woude GF: Met induces diverse mammary carcinomas in mice and is associated with human basal breast cancer. Proc Natl Acad Sci U S A 2009, 106:12909-12914

53. Ponzo MG, Lesurf R, Petkiewicz $S$, O'Malley FP, Pinnaduwage $D$, Andrulis IL, Bull SB, Chughtai N, Zuo D, Souleimanova M, Germain D, Omeroglu A, Cardiff RD, Hallett M, Park M: Met induces mammary tumors with diverse histologies and is associated with poor outcome and human basal breast cancer. Proc Natl Acad Sci U S A 2009, 106:12903-12908.

54. Turner N, Lambros MB, Horlings HM, Pearson A, Sharpe R, Natrajan R, Geyer FC, van Kouwenhove M, Kreike B, Mackay A, Ashworth A, van de Vijver MJ, Reis-Filho JS: Integrative molecular profiling of triple negative breast cancers identifies amplicon drivers and potential therapeutic targets. Oncogene, 29:2013-2023.

55. King MC, Marks JH, Mandell JB: Breast and ovarian cancer risks due to inherited mutations in BRCA1 and BRCA2. Science 2003, 302:643-646.

56. Lakhani SR, Jacquemier J, Sloane JP, Gusterson BA, Anderson TJ, van de Vijver MJ, Farid LM, Venter D, Antoniou A, Storfer-Isser A, Smyth E, Steel CM, Haites N, C., Goldgar D, Neuhausen S, Daly PA, Ormiston W, McManus R, Scherneck S, Ponder BA, Ford D, Peto J, Stoppa-Lyonnet D, Bignon YJ, Struewing JP, Spurr NK, Bishop DT, Klijn JG, Devilee P, et al:: Multifactorial analysis of differences between sporadic breast cancers and cancers involving BRCA1 and BRCA2 mutations. J Nat/ Cancer Inst 1998, 90:1138-1145.

57. Lakhani SR, Reis-Filho JS, Fulford L, Penault-Llorca F, van der Vijver M, Parry S, Bishop T, Benitez J, Rivas C, Bignon YJ, Chang-Claude J, ., Hamann U, Cornelisse CJ, Devilee P, Beckmann MW, Nestle-Kramling C, Daly PA, Haites N, Varley J, Lalloo F, Evans G, Maugard C, Meijers-Heijboer H, Klijn JG, Olah E, Gusterson BA, Pilotti S, Radice P, Scherneck S, Sobol H, et al:: Prediction of BRCA1 status in patients with breast cancer using estrogen receptor and basal phenotype. Clin Cancer Res 2005, 11:5175-5180.

58. Deng CX, Brodie SG: Roles of BRCA1 and its interacting proteins. Bioessays 2000, 22:728-737.

59. McCabe N, Turner NC, Lord CJ, Kluzek K, Bialkowska A, Swift S, Giavara S, O'Connor MJ, Tutt AN, Zdzienicka MZ, Smith GC, Ashworth A: Deficiency in the repair of DNA damage by homologous recombination and sensitivity to poly(ADP-ribose) polymerase inhibition. Cancer Res 2006, 66:8109-8115.

60. Donawho CK, Luo Y, Penning TD, Bauch JL, Bouska JJ, Bontcheva-Diaz VD, Cox BF, DeWeese TL, Dillehay LE, Ferguson DC, Ghoreishi-Haack NS, Grimm DR Guan R, Han EK, Holley-Shanks RR, Hristov B, Idler KB, Jarvis K, Johnson EF, Kleinberg LR, Klinghofer V, Lasko LM, Liu X, Marsh KC, McGonigal TP, Meulbroek JA, Olson AM, Palma JP, Rodriguez LE, Shi Y, et al:: ABT-888, an orally active poly(ADP-ribose) polymerase inhibitor that potentiates DNAdamaging agents in preclinical tumor models. Clin Cancer Res 2007, 13:2728-2737

61. Rottenberg S, Jaspers JE, Kersbergen A, van der Burg E, Nygren AO, Zander SA, Derksen PW, de Bruin M, Zevenhoven J, Lau A, Boulter R, Cranston A, O'Connor MJ, Martin NM, Borst P, Jonkers J: High sensitivity of BRCA1deficient mammary tumors to the PARP inhibitor AZD2281 alone and in combination with platinum drugs. Proc Natl Acad Sci U S A 2008, 105:17079-17084

62. Hoeijmakers $\mathrm{JH}$ : Genome maintenance mechanisms for preventing cancer. Nature 2001, 411:366-374.

63. Brodie SG, Xu X, Qiao W, Li WM, Cao L, Deng CX: Multiple genetic changes are associated with mammary tumorigenesis in Brca1 conditional knockout mice. Oncogene 2001, 20:7514-7523.

64. Xu X, Qiao W, Linke SP, Cao L, Li WM, Furth PA, Harris CC, Deng CX: Genetic interactions between tumor suppressors Brca1 and p53 in apoptosis, cell cycle and tumorigenesis. Nat Genet 2001, 28:266-271.

65. Smolen GA, Muir B, Mohapatra G, Barmettler A, Kim WJ, Rivera MN, Haserlat SM, Okimoto RA, Kwak E, Dahiya S, Garber JE, Bell DW, Sgroi DC, Chin L, Deng CX, Haber DA: Frequent met oncogene amplification in a Brca1/Trp53 mouse model of mammary tumorigenesis. Cancer Res 2006, 66:3452-3455.

66. Carracedo A, Egervari K, Salido M, Rojo F, Corominas JM, Arumi M, Corzo C, Tusquets I, Espinet B, Rovira A, Albanell J, Szollosi Z, Serrano S, Sole F: FISH and immunohistochemical status of the hepatocyte growth factor receptor (c-Met) in 184 invasive breast tumors. Breast Cancer Res 2009, 11:402.

67. Oliveras-Ferraros C, Vazquez-Martin A, Lopez-Bonet E, Martin-Castillo B, Del Barco S, Brunet J, Menendez JA: Growth and molecular interactions of the anti-EGFR antibody cetuximab and the DNA cross-linking agent cisplatin in gefitinib-resistant MDA-MB-468 cells: new prospects in the treatment of triple-negative/basal-like breast cancer. Int J Oncol 2008, 33:1165-1176.
68. Schneider BP, Winer EP, Foulkes WD, Garber J, Perou CM, Richardson A, Sledge GW, Carey LA: Triple-negative breast cancer: risk factors to potential targets. Clin Cancer Res 2008, 14:8010-8018.

69. Segal NH, Saltz LB: Evolving treatment of advanced colon cancer. Annu Rev Med 2009, 60:207-219.

70. Lynch TJ, Bell DW, Sordella R, Gurubhagavatula S, Okimoto RA, Brannigan BW Harris PL, Haserlat SM, Supko JG, Haluska FG, Louis DN, Christiani DC, Settleman J, Haber DA: Activating mutations in the epidermal growth factor receptor underlying responsiveness of non-small-cell lung cancer to gefitinib. N Engl J Med 2004, 350:2129-2139.

71. Paez JG, Janne PA, Lee JC, Tracy S, Greulich H, Gabriel S, Herman P, Kaye FJ, Lindeman N, Boggon TJ, Naoki K, Sasaki H, Fujii Y, Eck MJ, Sellers WR, Johnson BE, Meyerson M: EGFR mutations in lung cancer: correlation with clinical response to gefitinib therapy. Science 2004, 304:1497-1500.

72. Niemann C, Brinkmann V, Spitzer E, Hartmann G, Sachs M, Naundorf H, Birchmeier W: Reconstitution of mammary gland development in vitro: requirement of c-met and c-erbB2 signaling for branching and alveolar morphogenesis. J Cell Biol 1998, 143:533-545.

73. Engelman JA, Zejnullahu K, Mitsudomi T, Song Y, Hyland C, Park JO, Lindeman N, Gale CM, Zhao X, Christensen J, Kosaka T, Holmes AJ, Rogers AM, Cappuzzo F, MokT, Lee C, Johnson BE, Cantley LC, Janne PA: MET amplification leads to gefitinib resistance in lung cancer by activating ERBB3 signaling. Science 2007, 316:1039-1043.

74. Turke AB, Zejnullahu K, Wu YL, Song Y, Dias-Santagata D, Lifshits E, Toschi L, Rogers A, MokT, Sequist L, Lindeman NI, Murphy C, Akhavanfard S, Yeap BY, Xiao Y, Capelletti M, lafrate AJ, Lee C, Christensen JG, Engelman JA, Janne PA: Preexistence and clonal selection of MET amplification in EGFR mutant NSCLC. Cancer Cell, 17:77-88.

75. Bean J, Brennan C, Shih JY, Riely G, Viale A, Wang L, Chitale D, Motoi N, Szoke J, Broderick S, Balak M, Chang WC, Yu CJ, Gazdar A, Pass H, Rusch V, Gerald W, Huang SF, Yang PC, Miller V, Ladanyi M, Yang CH, Pao W: MET amplification occurs with or without T790M mutations in EGFR mutant lung tumors with acquired resistance to gefitinib or erlotinib. Proc Natl Acad Sci U S A 2007, 104:20932-20937

76. Mueller KL, Hunter LA, Ethier SP, Boerner JL: Met and c-Src cooperate to compensate for loss of epidermal growth factor receptor kinase activity in breast cancer cells. Cancer Res 2008, 68:3314-3322.

77. Kouros-Mehr H, Slorach EM, Sternlicht MD, Werb Z: GATA-3 maintains the differentiation of the luminal cell fate in the mammary gland. Cell 2006, 127:1041-1055.

78. Voduc D, Cheang M, Nielsen T: GATA-3 expression in breast cancer has a strong association with estrogen receptor but lacks independent prognostic value. Cancer Epidemiol Biomarkers Prev 2008, 17:365-373.

79. Comoglio PM, Giordano S, Trusolino L: Drug development of MET inhibitors: targeting oncogene addiction and expedience. Nat Rev Cancer 2008, 7:504-516.

80. Eder JP, Vande Woude GF, Boerner SA, LoRusso PM: Novel therapeutic inhibitors of the c-Met signaling pathway in cancer. Clin Cancer Res 2009, 15:2207-2214.

81. Cecchi F, Rabe DC, Bottaro DP: Targeting the HGF/Met signalling pathway in cancer. Eur J Cancer 2010, 46:1260-1270.

82. Kang JY, Dolled-Filhart M, Ocal IT, Singh B, Lin CY, Dickson RB, Rimm DL, Camp RL: Tissue microarray analysis of hepatocyte growth factor/Met pathway components reveals a role for Met, matriptase, and hepatocyte growth factor activator inhibitor 1 in the progression of node-negative breast cancer. Cancer Res 2003, 63:1101-1105.

83. Lengyel E, Prechtel D, Resau JH, Gauger K, Welk A, Lindemann K, Salanti G, Richter T, Knudsen B, Vande Woude GF, Harbeck N: C-Met overexpression in node-positive breast cancer identifies patients with poor clinical outcome independent of Her2/neu. Int J Cancer 2005, 113:678-682.

84. Lindemann K, Resau J, Nahrig J, Kort E, Leeser B, Annecke K, Welk A, Schafer J, Vande Woude GF, Lengyel E, et al:: Differential expression of c-Met, its ligand HGF/SF and HER2/neu in DCIS and adjacent normal breast tissue. Histopathology 2007, 51:54-62.

85. Eichbaum MH, de Rossi TM, Kaul S, Bruckner T, Schneeweiss A, Sohn C: Serum levels of hepatocyte growth factor/scatter factor in patients with liver metastases from breast cancer. Tumour Bio/ 2007, 28:36-44.

doi:10.1186/bcr2617

Cite this article as: Gastaldi S, et al.: The Met oncogene and basal-like breast cancer: another culprit to watch out for? Breast Cancer Research 2010, 12:208. 